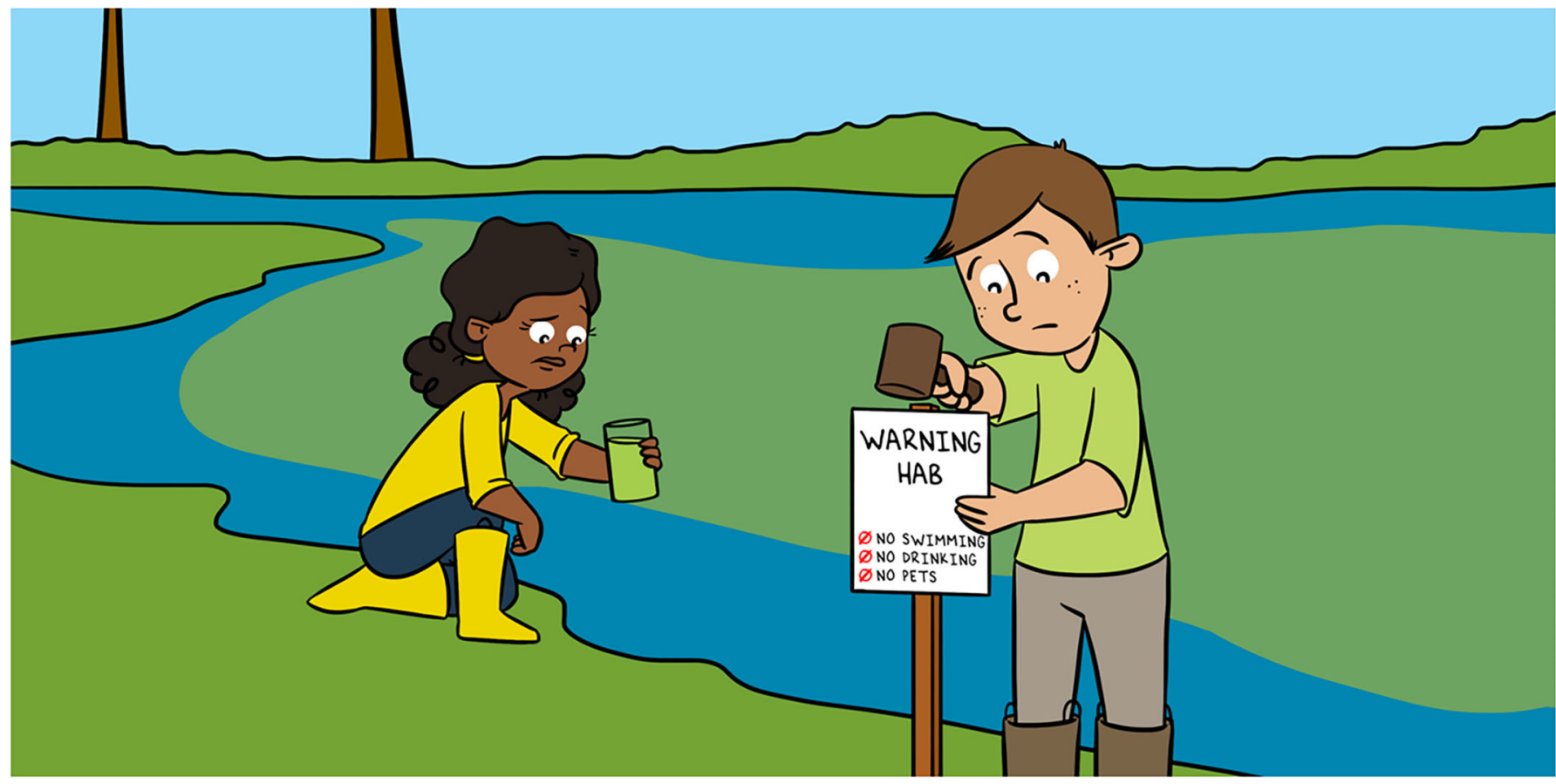

\title{
ARE YOU A HAB WARRIOR?
}

\section{Peggy W. Lehman ${ }^{1 *}$, Tomofumi Kurobe ${ }^{2+}$, Timothy G. Otten ${ }^{3}$ and Melissa B. Peacock ${ }^{4 t}$ \\ ${ }^{1}$ California Department of Water Resources, West Sacramento, CA, United States \\ ${ }^{2}$ Department of Anatomy, Physiology and Cell Biology, School of Veterinary Medicine, University of California, Davis, Davis, CA, United States \\ ${ }^{3}$ Bend Genetics, Sacramento, CA, United States}

${ }^{4}$ Northwest Indian College, Bellingham, WA, United States

YOUNG REVIEWERS:

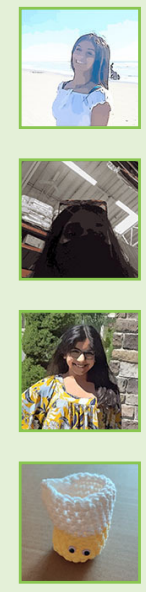

MEHA

AGE: 15

NIVEDITA

AGE: 14

SHREEYA

AGE: 11

SHRIYA

AGE: 13
Microalgae and cyanobacteria are tiny, microscopic plant-like organisms that float in the water and grow using nutrients from the water, energy from the sun and carbon dioxide gas from the air. Most microalgae and cyanobacteria are helpful because, like grass for cows on land, they provide food for aquatic animals. However, some microalgae and cyanobacteria are poisonous and when large numbers of them occur, they are called harmful algal blooms, or HABs for short. HABs can poison both humans and animals through the food they eat, the water they drink, and even the air they breathe. HABs are increasing within lakes, rivers, oceans, and estuaries worldwide because of pollution and climate change. This article will tell you about HABs in San Francisco Estuary, USA: who they are, what they look like, why they occur, how they affect plants, animals and people, and things you can do as a HAB warrior to stay safe and prevent their spread. 


\section{MICROALGAE}

Microalgae are microscopic algae that grow in waterbodies like rivers and oceans. They create sugars for growth using light from the sun, nutrients from the water and carbon dioxide from the air by a process called photosynthesis.

CYANOBACTERIA

Cyanobacteria are microscopic bacteria that live in the water and, like microalgae, produce sugars for growth using light from the sun, nutrients from the water and carbon dioxide from the air by a process

called photosynthesis.

\section{ESTUARY}

An estuary is a place where the river water meets the ocean water as it moves inland due to the tide. Tides are the daily rise and fall of ocean water due to the attraction of the moon and sun.

1 https://kids.

frontiersin.

org/articles/

10.3389/frym

2021.611976

\section{ZOOPLANKTON}

Zooplankton are tiny animals that float in the water of rivers, lakes, oceans, and estuaries. Some zooplankton are microscopic, but others, like jellyfish are visible with the naked eye.

\section{AQUATIC FOOD} WEB

A description of who eats whom in the water, which usually progresses from smaller to larger organisms

\section{WHAT ARE HABS?}

Harmful algal blooms, or HABs for short, are poisonous microscopic and floating plant-like organisms composed of microalgae and cyanobacteria that may cover broad areas of rivers, lakes, estuaries, or oceans. Most coastal areas of the world experience marine HABs each year. The HABs that form these blooms are so small (less than the diameter of a strand of hair) that we need a high-powered microscope to see them clearly. Microalgae and cyanobacteria convert light energy from the sun, nutrients from the water and carbon dioxide gas from the air into the sugars that they need to grow, through a process called photosynthesis ${ }^{1}$. This process is also used by the plants on land that you know so well.

Like grass for cows, microalgae, and cyanobacteria are important sources of food for aquatic animals such as tiny zooplankton, fish, or clams. Microalgae and cyanobacteria are particularly important because they produce oxygen for us to breathe and remove carbon dioxide from the air, a gas that is increasing due to human pollution and causing climate change.

\section{WHY ARE HABS POISONOUS?}

Most microalgae and cyanobacteria are not poisonous and provide healthy food for animals in the water column as a part of the aquatic food web. However, some microalgae and cyanobacteria produce poisons that slow the growth of other microalgae and cyanobacteria and may make humans and animals very sick. The poisons HABs produce can be strong enough to kill or harm plants or animals of any size, including fish, dogs, livestock, sea otters, and whales, just to name a few [1]. People and their pets may get sick after swimming in, drinking, or eating food that came from water containing a HAB. Some $\mathrm{HAB}$ poisons can even float in the air we breathe.

\section{HOW DO YOU KNOW IF WATER HAS A HAB?}

Identifying a HAB can be difficult without a microscope, but there are some clues you can use (Figure 1). Is the water bright green, brown, or red? Does the surface have a thick mat of green or yellow-green slime? Is there a thick scum or bubbly mass? Are there large, green, irregular chunks that look like flakes floating on the surface of the water? Are dead fish floating in the water? If you can answer yes to any of these questions, then the water may contain a HAB.

\section{HOW DO MICROALGAE AND CYANOBACTERIA BECOME HABS?}

Scientists are not sure why some microalgae and cyanobacteria become poisonous HABs. In fact, many of the microalgae and 
Figure 1

(A) A Microcystis bloom in Pinto Lake, CA, USA turned the water bright green. (B) The

Microcystis bloom in Lake Taihu, China becames so thick that it looked like green paint.

(C) Dinoflagellate blooms turned the water red off the coast of Florida, USA (https://www.cdc.gov/ habs/images/habshomepage-image.jpg). (D) Microcystis blooms in Pinto Lake, CA, USA. (E) Microcystis blooms in San Francisco

Estuary can look like masses of flakes in the water. (F) Dead animals can be a sign of a HAB.

\section{BACTERIA}

Bacteria are microscopic simple single-celled organisms which have an outer cell wall but lack internal structures to hold its cellular components, including its genetic material.
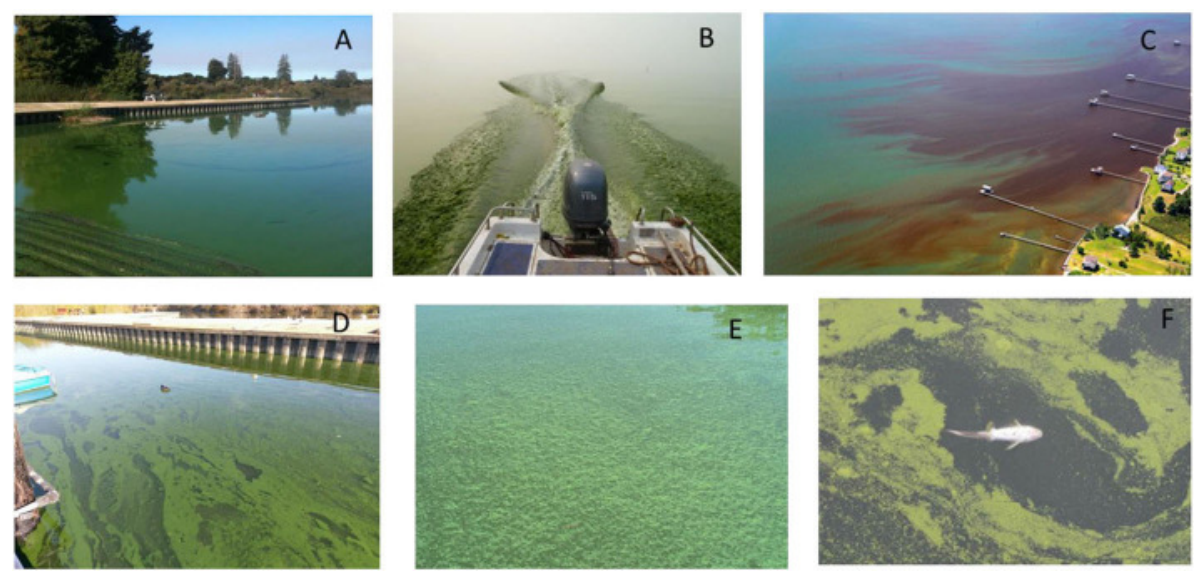

Figure 1

cyanobacteria that form HABs are not always poisonous. Initially, it was thought that HABs made toxins to poison aquatic animals that tried to eat them, like zooplankton. This is a common defense mechanism used against predators by some insects, such as Monarch butterflies. Other scientists found that HAB toxins were produced to protect against bright light. New genetic research suggests that HABs release toxins into the water to poison nearby bacteria that compete with them for nutrients. As it turns out, the bacteria also release toxins into the water to poison the HABs, creating thousands of biological combat zones within each drop of water! It is likely that HABs make toxins to meet multiple needs.

The reasons why some microalgae and cyanobacteria developed the ability to produce poisons remains a scientific mystery. Even within one species, some microalgal and cyanobacteria cells produce toxins, and some do not. Adding to the intrigue is the fact that HABs evolved before their predators did. So, it is unlikely that the original reason for producing poison was as a defense mechanism. Hopefully, scientists will eventually discover why HABs produce poisons, so they can come up with more efficient ways to stop them. Scientists may even discover ways to use the toxins. Many microalgae and cyanobacteria produce substances that have beneficial applications, such as food supplements, anti-cancer drugs, cosmetics, or thickening agents.

HABs usually form in areas where the water is polluted by high concentrations of nutrients from wastewater, fertilizer, or industrial chemicals [2]. Other chemicals used to grow crops or raise livestock can also increase HABs. HABs also tend to form when water temperatures are warm. The rising air temperatures due to climate change are causing water to stay warm longer, allowing HABs to last longer each year. Lastly, when the natural flow of rivers is changed by building dams and reservoirs, rivers flow more slowly, which increases the potential for HABs to accumulate. In San Francisco 
Figure 2

CoastWatch satellite imagery allows scientists to map the presence of HABs formed by the dinoflagellate Karenia brevis in the Gulf of Mexico, along the southeast boarder of the United States. Red colors indicate where the dinoflagellate is abundant (Image credit: https:// coastwatch.noaa. gov/cw/stories/ how-our-data-areused/harmfulalgal-bloommonitoring-andforecasting-inthe-gulf-ofmexico.html).

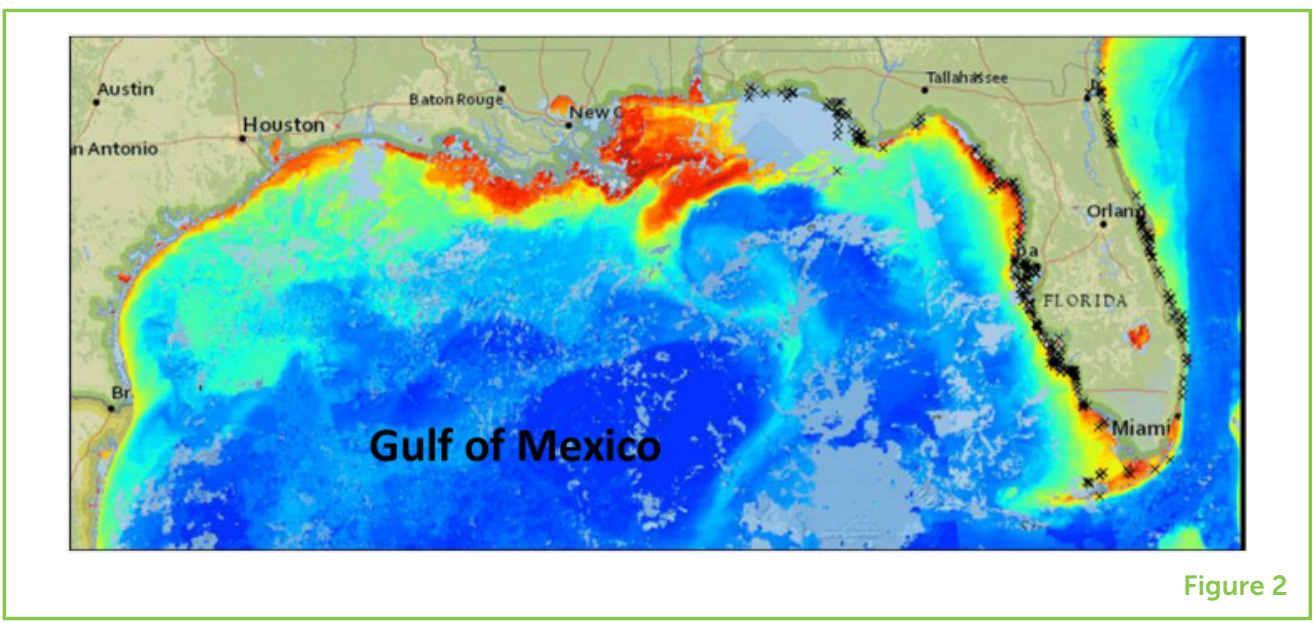

Estuary, where HABs commonly occur, nutrient concentrations and water temperatures are high, and the water moves slowly due to manmade structures such as levees and dams.

\section{WHY ARE WE WORRIED ABOUT HABS IN SAN FRANCISCO ESTUARY?}

Scientists in the San Francisco Estuary are worried about HABs because they are occurring more often, getting bigger, lasting longer, and becoming more poisonous, especially during dry years [3]. The warm water temperatures and slow-moving rivers during dry years allow HABs to grow rapidly and accumulate in the estuary's freshwater rivers and salty bays.

In the freshwater rivers of the estuary, cyanobacteria, have formed HABs since 1999. Cyanobacteria HAB species look like little green balls or long strings under a microscope, and they usually turn the water's surface bright green, like paint was spilled on it. A scum on the surface of the water is a common example of what many HABs look like. Scums from some of these HAB blooms are so large that they can be seen by satellites from outer space (Figure 2)!

Cyanobacteria produce poisons that cause cancer, affect the muscles, and impair the growth and survival of non-poisonous microalgae and cyanobacteria, zooplankton, and fish. Studies in San Francisco Estuary showed that the poisons produced by one type of cyanobacteria called Microcystis accumulate in the tissues of young fish, clams, zooplankton, and even worms. Fish exposed to Microcystis were unhealthy and developed liver disease [4]. Sometimes HABs even affect animals through the bacteria that surround them. In one study, Microcystis poisoned baby fish by increasing the amount of Aeromonas bacteria, a type of bacteria that kills fish [5]. 
2 https://www npr.org/sections /health-shots/ 2017/11/09 /563073022/ algae-contaminates -drinking-water

\section{DINOFLAGELLATES}

Dinoflagellates are microalgae in the phylum Dinoflagellata and swim in the water using two tail-like flagella. Although they can grow using photosynthesis, they can also eat other microalgae.

\section{DIATOMS}

Diatoms are microalgae in the phylum Bacillariophyta. They have a shell made of silica that looks like a tiny glass box. Because their shell is heavy, diatoms often live on the bottom of rivers or lakes and need lots of mixing by wind and tide to stay in the water column.
Cyanobacteria poisons can also make people sick if they accidentally drink the water when swimming, or if they drink water that is not correctly treated. In 2014, a state of emergency occurred in Ohio, USA, when Microcystis from Lake Erie poisoned the drinking water of a half a million people ${ }^{2}$. The Microcystis HAB in the rivers of San Francisco Estuary could affect the water used by up to 25 million people!

In the salty, shallow bays of the estuary and areas close to the ocean, we also find HABs caused by types of microalgae known as dinoflagellates and diatoms. Dinoflagellates often look like soccer balls with tails wrapped around their middles. They can turn the water bright red or brown during the day and make it glow at night. Diatoms are encased in silica shells that look like tiny, carved glass boxes. These microalgae turn the water bright green and can make the water look bubbly near the shore.

Dinoflagellate and diatom HABs can accumulate in seafood, including fish, clams, and oysters, making these foods poisonous. Humans, marine mammals, and birds that eat these shellfish can become sick [6]! The presence of HAB poisons in food also affects the economy, through impacts on fishery-related businesses like the shellfish industry. When fish are poisonous, fishermen cannot sell them to a market, which in turn cannot sell fish to restaurants, which then cannot sell fish to their customers.

\section{HOW CAN YOU BECOME A HAB WARRIOR?}

You can be a HAB warrior by helping to protect others and reduce the spread of HABs. Learn how to identify potential HABs. If you see a HAB, keep yourself and your animals away from it, and warn others. Contact a local water agency or your school to alert them to the potential problem. Join a citizen science group that collects water at local lakes to be tested for HABs. Stay alert to reports of HABs in the news or signs at local waterways and be sure the fish and shellfish you eat come from areas without HABs (Figure 3).

You can also fight against HABs by reducing pollution. Poisonous microalgae and cyanobacteria occur where nutrients from industrial pollution and fertilizer runoff are high. So, try to reduce the amount of nutrients and chemicals in the water by recycling and careful use of chemicals. Avoid applying large quantities of fertilizers, which can run into waterways after heavy rains. Reduce the production of gases like carbon dioxide that heat the air by reducing energy use. Turn off lights and electrical devices when not in use, reduce fossil fuel use by walking, biking, or using public transportation, and recycle.

Finally, consider being a HAB scientist! We need people like you to develop models and warning systems to protect people from HABs, determine why HABs become poisonous, develop technologies to 
Figure 3

Watch for warning symbols and signs like these near waterways, to know when it is not safe to enter or use the water (Image credit: https:// mywaterquality.ca. gov/habs/).

\section{WARNING}

\section{Toxins from algae in this water can harm people and kill animals}

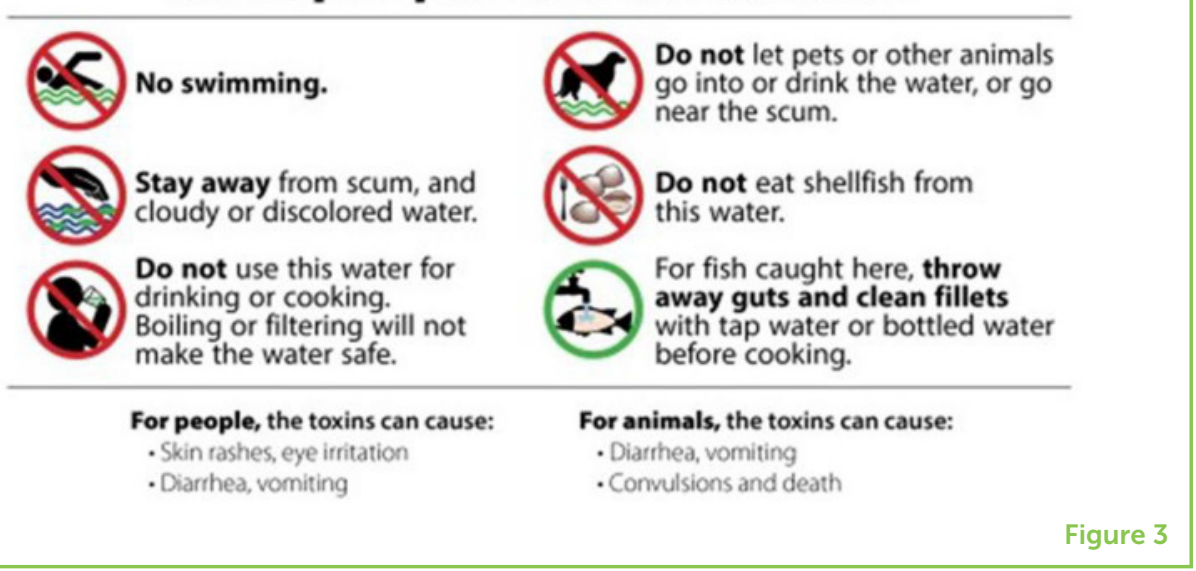

monitor HABs and make them less toxic, and importantly, to determine how HABs can be prevented. If both scientists and the public work together as HAB warriors, we can preserve the health of waterways, aquatic ecosystems, animals, and humans!

\section{ACKNOWLEDGMENTS}

We would like to thank the Interagency Ecological Program and the California Department of Water Resources for providing staff time and resources to support this effort.

\section{REFERENCES}

1. Miller, M. A., Kudela, R. M., Mekebri, A., Crane, D., Oates, S. C., Tinker, M. T., et al. 2010. Evidence for a novel marine harmful algal bloom, cyanotoxin (microcystin) transfer from land to sea otters. PLOS ONE 5:e12576. doi: 10.1371/journal.pone. 0012576

2. Paerl, H. W., and Otten, T. G. 2013. Harmful cyanobacterial blooms: causes, consequences, and controls. Environ. Microbiol. 65:995-1010. doi: 10.1007/ s00248-012-0159-y

3. Lehman, P. W., Kuobe, T., Lesmeister, S., Baxa, D., Tung, A., and Teh, S. J. 2017. Impacts of the 2014 severe drought on the Microcystis bloom in San Francisco Estuary. Harmful Algae 63:94-108. doi: 10.1016/j.hal.2017.01.011

4. Acuña, S., Deng, D.-F., Lehman, P. W., and Teh, S. J. 2012. Sublethal dietary effects of microcystis on Sacramento splittail, Pogonichthys macrolepidotus. Aquat. Toxicol. 110-1:1-8. doi: 10.1016/j.aquatox.2011.12.004

5. Kurobe, T., Lehman, P. W., Haque, Md. E., Sedda, T., Lesmeister, S., and Teh, S. 2018. Evaluation of water quality during successive severe drought years within 
Microcystis blooms using fish embryo toxicity tests for the San Francisco Estuary, California. Sci. Total Environ. 610-1:1029-37. doi: 10.1016/j.scitotenv. 2017.07.267

6. Peacock, M. B., Gibble, C. M., Senn, D. B., Cloern, J. E., and Kudela, R. M. 2018. Blurred lines: multiple freshwater and marine algal toxins at the land-sea interface of San Francisco Bay, California. Harmful Algae 73:138-47. doi: 10.1016/j.hal.2018.02.005

SUBMITTED: 28 September 2020; ACCEPTED: 19 July 2021; PUBLISHED ONLINE: 26 August 2021.

EDITED BY: Mahasweta Saha, Plymouth Marine Laboratory, United Kingdom

CITATION: Lehman PW, Kurobe T, Otten TG and Peacock MB (2021) Are You a HAB Warrior? Front. Young Minds 9:611282. doi: 10.3389/frym.2021.611282

CONFLICT OF INTEREST: TO is the director at Bend Genetics, LLC.

The remaining authors declare that the research was conducted in the absence of any commercial or financial relationships that could be construed as a potential conflict of interest.

COPYRIGHT @ 2021 Lehman, Kurobe, Otten and Peacock. This is an open-access article distributed under the terms of the Creative Commons Attribution License (CC BY). The use, distribution or reproduction in other forums is permitted, provided the original author(s) and the copyright owner(s) are credited and that the original publication in this journal is cited, in accordance with accepted academic practice. No use, distribution or reproduction is permitted which does not comply with these terms.

\section{YOUNG REVIEWERS}

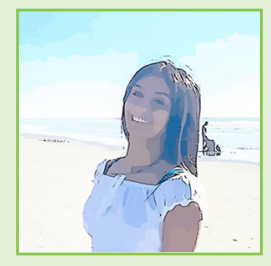

\section{MEHA, AGE: 15}

Hey, I am a sophomore in high school, and looking forward to a career in medicine. My hobbies include drawing, tennis, and just hanging out with friends! I also love to volunteer and give back to my community. I am excited to be a part of Frontiers for Young Minds, as I want my peers and other students to be able to access these great scientific accomplishments made every day.

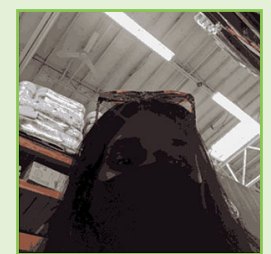

\section{NIVEDITA, AGE: 14}

Hi I am Nivedita, my pronouns are she/her/hers, and I am excited to start this year off! A little about me, I love listening to music in my free time (Frank Ocean is a favorite (:) and I like to draw when I can. I like hanging out my friends, and my favorite subject is chemistry! 

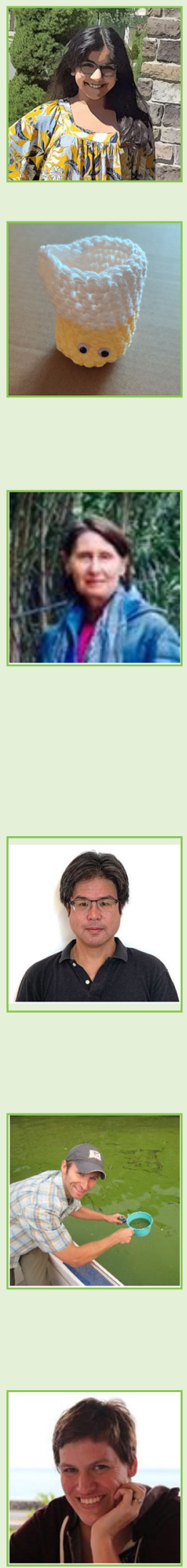

\section{SHREEYA, AGE: 11}

Hi my name is Shreeya. I live with my sister and my parents. In my free time I like to walk with friends, play board games, and doing karate. During this time, I have been keeping myself busy by talking with my friends, reading Harry Potter books, and finishing a 3D Hogwarts Puzzle.

\section{SHRIYA, AGE: 13}

$\mathrm{Hi}$, my name is Shriya. I live in the U.S. I am in eighth grade, and my favorite subjects are science and math. In my free time, I like to dance and do art. I just started working with Frontiers for Young Minds, and am very excited to continue!

\section{AUTHORS}

\section{PEGGY W. LEHMAN}

I am a Ph.D. ecologist with a specialty in phytoplankton and work as a senior scientist for the State of California, USA. My research includes the growth, causes, and ecosystem impacts associated with Microcystis harmful algal blooms in the freshwater reaches of San Francisco Estuary. I also study the phytoplankton in rivers and wetlands within the estuary in response to environmental conditions, including climate change. In my free time, I enjoy watching changes in phytoplankton blooms as I kayak through rivers and lakes near home. *Peggy.Lehman awater.ca.gov. To find out more about my work see ${ }^{\dagger}$ orcid.org/0000-0001-9556-0542.

\section{TOMOFUMI KUROBE}

I am an assistant professor in aquatic toxicology at the University of California, Davis. I have been investigating various ecological issues, including impacts of contaminants like pharmaceutical and personal care products, algal toxins, and pesticides, on aquatic organisms such as phytoplankton, copepods, and fishes. My goal is to reduce ecological issues using scientific knowledge. Are you interested in water quality? Please email me: tkurobe@ucdavis.edu; ${ }^{\dagger}$ orcid.org/0000-0003-3906-1989.

\section{TIMOTHY G. OTTEN}

I am a public health microbiologist interested in studying the feedback between human activities that make the environment "sick"-such as nutrient pollution that causes algal blooms-and how these blooms in turn have the potential to make humans sick. I founded a water quality laboratory in Sacramento, CA that is dedicated to all aspects of harmful algal bloom testing. Please email me with any questions at: ottentimabendgenetics.com

\section{MELISSA B. PEACOCK}

I am a phytoplankton ecologist and the director of the Salish Sea Research Center at Northwest Indian College in Bellingham, Washington. The research center promotes the development of students as indigenous scholars. My research focuses on freshwater and marine biotoxins, and their transfer into the marine food web through shellfish. I work on projects that are community identified, focus on food sovereignty, and involve a network of partners with different backgrounds. Please email me at: mpeacock@ anwic.edu or my ORCID ID: ${ }^{\dagger}$ orcid.org/0000-0002-0970-6523. 